\title{
PENGEMBANGAN KURIKULUM INTEGRATIF ISLAM, LOCAL VALUE, INTERNATIONAL MINDEDNESS DI KINDY AFKAARUNA ISLAMIC SCHOOL
}

\author{
NOVI FATKHIYATUL MUYASSAROH \\ Universitas Islam Negeri Sunan Kalijaga Yogyakarta \\ Email: mayamuyassaroh@gmail.com \\ SUYADI \\ Universitas Islam Negeri Sunan Kalijaga Yogyakarta \\ Email: suyadi@uinsuka.ac.id
}

Article received: 02 Maret 2020, Review process: 18 Juni 2020, Article Accepted:18 September 2020, Article published: 30 September 2020

\begin{abstract}
The curriculum is the basis of an educational institution in order to help the achievement of the objectives that have been set. The background of this research is that there is an innovation of curriculum development in Afkaaruna Islamic School of aligning the three elements of value, Islamic, local and international thinking. The purpose of this research is to know how the development of integrative curriculum used by the institutions. Methods This study included descriptive qualitative research with researchers as subjects, method of collecting data through observation, documentation and interview. Results from this study data showed that the curriculum in Kindy Afkaaruna Islamic School, referring to International Preschool Curriculum (IPC) collaborated curriculum with the curriculum Ministry of religion (KEMENAG), synchronized to Afkaaruna Learning Pack (ALP) that cover English, al-Dirasah al-Islamiyyah, and local value.
\end{abstract}

Keywords: integrative curriculum, Islamic, local, international

\begin{abstract}
Abstrak
Kurikulum merupakan dasar dari suatu lembaga pendidikan guna membantu ketercapaian tujuan yang telah ditetapkan. Latar belakang penelitian ini adalah adanya sebuah inovasi dari pengembangan kurikulum di Afkaaruna Islamic School yang menyelaraskan tiga unsur nilai, keislaman, lokal dan pemikiran internasional. Tujuan dari penelitian ini adalah mengetahui bagaimana pengembangan kurikulum integratif yang digunakan oleh Kindy Afkaaruna Islamic School. Metode penelitian ini termasuk penelitian kualitatif deskriptif, teknik pengumpulan data menggunakan observasi, dokumentasi dan wawancara. Hasil dari penelitian ini diperoleh data bahwa kurikulum di Kindy Afkaaruna Islamic School, mengacu pada kurikulum International Preschool Curriculum (IPC) yang dikolaborasikan dengan
\end{abstract}


AWLADY: Jurnal Pendidikan Anak

Homepage: www.syekhnurjati.ac.id/jurnal/index.php/awlady

Email : pgrasyekhnurjati@gmail.com

P-ISSN: 2541-4658

E-ISSN: 2528-7427

kurikulum kemenag, disinkronkan dengan paket belajar Afkaaruna Learning Pack (ALP) mencakup bahasa inggris, al-Dirassah al-Islamiyah dan nilai lokal.

Kata Kunci: kurikulum integratif, keislaman, lokal, internasional

\section{PENDAHULUAN}

Kurikulum merupakan salah satu komponen yang memiliki peranan penting dalam sistem pendidikan sebagai alat dan pedoman dalam proses pembelajaran di sekolah yang relevan dengan kebutuhan dan tuntutan masyarakat. Agar tercapainya suatu tujuan pendidikan, dibutuhkan sistem pengelolaan atau penataan terhadap kurikulum secara kooperatif, komperhensif, sistemik dan sistematik yang dijadikan sebagai acuan oleh lembaga pendidikan dalam rangka mewujudkan tujuan pendidikan. Melalui kurikulum, siswa akan memahami apa yang harus dicapai, isi atau bahan pembelajaran apa yang harus dikuasai, dan pengalaman belajar seperti apa yang harus dilakukan sekolah (Wina Sanjaya 2008, p, 5)

Kegiatan pengelolaan kurikulum menjadi bagian penting mengingat kurikulum sebagai inti pendidikan. Pertimbangan kebijakan dari pemerintah maupun Departemen Pendidikan Nasional, Pada tingkat satuan pendidikan kegiatan kurikulum lebih mengutamakan untuk merealisasikan dan merelevansikan antara kurikulum nasional dengan kebutuhan daerah dan kondisi sekolah yang bersangkutan, sehingga kurikulum tersebut merupakan kurikulum yang integritas dengan peserta didik maupun dengan lingkungan di mana sekolah itu berada (Rusman 2009, 4)

Dalam pelaksanaannya, manajemen kurikulum harus dikembangkan sesuai dengan konteks manajemen berbasis sekolah. Oleh karena itu, otonomi diberikan pada lembaga pendidikan atau sekolah dalam mengelola kurikulum secara mandiri dengan memprioritaskan kebutuhan dan ketercapaian sasaran visi dan misi lembaga pendidikan atau sekolah dengan tidak mengabaikan kebijakan nasional yang telah ditetapkan (Irjus Indrawan 2012, 8)

Tatanan Manajemen kurikulum yang baik akan berpengaruh terhadap kegiatan implementasi kurikulum meliputi; pengelolaan perencanaan kurikulum; pengelolaan implementasi kurikulum; pengelolaan ekstrakurikuler dan kokurikuler; pengelolaan pelaksanaan evaluasi kurikulum; pengelolaan perumusan penetapan kriteria dan pelaksanaan kelulusan; dan pengelolaan pengembangan media dan sumber belajar (Rusman 2009, 19) 
AWLADY: Jurnal Pendidikan Anak

Homepage: www.syekhnurjati.ac.id/jurnal/index.php/awlady

Email : pgrasyekhnurjati@gmail.com

P-ISSN: 2541-4658

E-ISSN: 2528-7427

Pengelolaan Perencanaan kurikulum merupakan langkah pertama yang harus dilakukan dalam merumuskan atau mengimplementasikan kurikulum suatu lembaga (Dinn Wahyudin 2014, p, 22). Beberapa hal yang harus diperhatikan dalam proses perencanaan kurikulum diantaranya adalah siapa yang bertanggung jawab dalam pelaksanaan kurikulum dan bagaimana perencanaan kurikulum itu direncanakan secara profesional.

Pelaksanaan perencanaan tersebut dapat melalui pendekatan yang bersifat Administrative Approach yaitu kurikulum direncanakan oleh pihak atasan, kemudian diturunkan kepada instansi-instansi bawahan sampai kepada guru. Dalam konteks ini, guru tidak dilibatkan, mereka sebagai penerima dan pelaksana di lapangan. Sehingga semua ide, gagasan atau inisiatif berasal dari pihak atasan. Dan pendekatan selanjutnya adalah Grass Roots Approach dimana pihak guru dan kepala sekolah ikut andil dalam merencanakan atau melakukan perubahan kurikulum, serta memberikan ide, gagasan dan inisiatif (Nasbi, 2017)

J.G Owen menekankan bahwa perlunya keterlibatan guru dalam melakukan perencanaan kurikulum. Guru harus bertanggung jawab dalam perencanaan kurikulum karena dalam praktek mereka adalah pelaksana kurikulum yang sudah disusun bersama (Oemar Hamalik 2009, p, 151).

Pada era globalisasi ini banyak perubahan yang terjadi, dari mulai gaya hidup masyarakat, pola hidup masyarakat, dan kemajaun teknologi, globalisasi tersebut juga berpengaruh pada bidang pendidikan (Spring, J 2009). Spring mengatakan bahwa dampak dari globalisasi dalam dunia pendidikan memunculkan sekolah-sekolah Franchise di seluruh dunia. Ada kecenderungan beberapa sekolah Franchise yang kurang memperhatikan pendidikan nasional berdasarkan ketetapan pemerintah. Mereka lebih fokus pada pendidikan manusia secara global (Spring, J, 2009).

Salah satu Kurikulum Franchise yang diterapkan di Indonesia adalah International Presschool Curriculum (IPC). Kurikulum dari Inggris yang diperkenalkan pada tahun 2008, berkantor pusat di Amerika Serikat. dikembangkan oleh tim akademisi doktor dan merupakan kurikulum Pendidikan Anak Usia Dini pertama di dunia, serta satu satunya kurikulum yang memenuhi beberapa standar nasional. Kemudian pada tahun 2016 diperkenalkan di Indonesia dan Malaysia melalui sebuah acara Ceremony penandatanganan lisensi eksklusif International Presschool Curriculum (IPC). Didirikan untuk memperkuat dan menyelaraskan Standar 
AWLADY: Jurnal Pendidikan Anak

Homepage: www.syekhnurjati.ac.id/jurnal/index.php/awlady

Email : pgrasyekhnurjati@gmail.com

P-ISSN: 2541-4658

E-ISSN: 2528-7427
Vol. 6, No. 2, September 2020

Pendidikan Anak Usia Dini. Sebagai asosiasi profesional yang secara langsung melayani sekolah, pelajar, orang tua dan pemerintah, IPC menawarkan serangkaian produk dan layanan unik yang mempromosikan pembelajaran aktif dan praktik efektif dalam pengajaran (the IPC family of schools, 2019)

IPC menawarkan program pelatihan guru yang luas melalui bimbingan atau kursus selama 6 bulan, guna memperkuat keterampilan mengajar guru serta membangun standar minimum untuk mengimplementasikan kurikulum tersebut. tujuan dari kurikulum IPC ini adalah guna menikmati pengakuan dan kerja global. IPC diakui secara internasional dan bekerja erat dengan pemerintah untuk mengubah materi kurikulum jika diminta untuk memastikan kepatuhan lokal (International Preschool Curriculum, 2019).

Fokus kajian penelitian ini adalah mengungkap bagaimana pengembangan kurikulum internasional yang diterapkan pada lembaga pendidikan yang bernaung di Kementrian Agama. Diketahui melalui observasi pra penelitian bahwa Afkaaruna Islamic school, merupakan lembaga yang menggunakan kurikulum IPC sebagai salah satu acuan mengelola kurikulum dalam konteks berbasis sekolah.

\section{METODOLOGI}

Metode penelitian ini adalah penelitian kualittaif. Lokasi penelitian di Afkaaruna Islamic School yang beralamat Jalan Kaliurang Km. 12,5, Dusun Pelem, Harjobinangun, Pakem, Kabupaten Sleman, Daerah Istimewa Yogyakarta 55581. Penelitian dilakukan dari tanggal 16 september 2019, yaitu peneliti melakukan wawancara non terstruktur dan 23 september 2019 peneliti mengambil data di sekolah, dilanjutkan pada tanggal 26 sampai 30 desember, peneliti melakukan wawancara terstruktur diluar kegiatan sekolah. Guna mendapatkan data yang relevan peneliti melakukan observasi secara langsung pada Tanggal 6 sampai 15 januari 2020. Disamping dokumen dokumen yang tersedia, adapun yang menjadi Key informan dalam penelitian ini adalah kepala sekolah Kindy Afkaaruna Islamic School. Metode pengumpulan data yang digunakan adalah observasi, wawancara (terstruktur dan non terstruktur), dan dokumentasi (Handphone). Teknik analisis data yang digunakan adalah reduksi data, display data berupa narasi, dan kesimpulan. 
AWLADY: Jurnal Pendidikan Anak

Homepage: www.syekhnurjati.ac.id/jurnal/index.php/awlady

Email : pgrasyekhnurjati@gmail.com

P-ISSN: 2541-4658

E-ISSN: 2528-7427
Vol. 6, No. 2, September 2020

\section{HASIL DAN PEMBAHASAN}

Salah satu lembaga pendidikan di Indonesia khususnya Daerah Istimewa Yogyakarta yang menerapkan kurikulum IPC adalah Afkaaruna Islamic School, lembaga pendidikan dibawah yayasan Abdul Djalil Sibaweh ini mengikuti konsep menyelaraskan tiga pilar yaitu: Islam, nilai lokal, dan pemikiran Internasional. Dengan memiliki penekanan pada tiga pilar ini, sekolah memberikan stimulus positif melalui kegiatan pembelajaran yang kreatif dan ramah. Memiliki tujuan bagi siswa untuk mengembangkan keingintahuan intelektual (Muhibbul 'ilmi) serta pendekatan yang inovatif untuk kehidupan, di kaitkan dengan nilainilai keislaman dan proses pembelajaran karena siswa belajar untuk menjunjung tinggi nlainilai lokal dan internasional (Afkaaruna Islamic School, 2019)

Adanya lembaga yang menerapkan tiga pilar tersebut, menangkis pernyataan dari Spring, bahwa tidak semua lembaga yang mengadopsi kurikulum Internasional (Franchise) kurang memperhatikan pendidikan Nasional yang ditetapkan oleh pemerintah, karena nilai lokal yang dikembangkan oleh Afkaaruna Islamic School mengacu kepada kurikulum yang ditetapkan oleh Kementrian Agama.

Berdasarkan hasil wawancara dengan kepala sekolah didapatkan data bahwa Afkaaruna Islamic School lahir dari sebuah kegelisahan terhadap Pendidikan Anak Usia Dini di Indonesia. Banyaknya sekolah berbasis Internasional yang ditawarkan dirasa kurang memberikan kepuasan hati. Kegelesihan tersebut semakin menjadi manakala kontribusi muslim terhadap ilmu pengetahuan belakangan ini semakin menurun. Salah satu pemicu terjadinya penurunan tersebut adalah kemampuan dalam berbahasa inggris yang kurang. Bahasa Inggris sebagai bahasa Internasional yang tidak dapat dipungkiri keberadaanya di era Globalisasi yang menuntut semua orang harus bisa menggunakannya. Hal tersebut dapat dilihat pada kenyataan saat ini bahwa seluruh akses ilmu pengetahuan kebanyakan menggunakan bahasa Inggris, urgensi penerapan bahasa Inggris sejak dini dirasa dapat membantu kesiapan anak dalam menghadapi kemajuan dunia (Sindy Saptaa. Wawancara, 16 september 2019).

Berdasarkan kegelisahan tersebut lahirlah suatu lembaga pendidikan anak usia dini dengan konsep tiga pilar yaitu islam, local value, dan International mindedness pada tahun 2016 di Yogjakarta (Sindy Saptaa. Wawancara, 16 september 2019). Berdasarkan data historis 
AWLADY: Jurnal Pendidikan Anak

Homepage: www.syekhnurjati.ac.id/jurnal/index.php/awlady

Email : pgrasyekhnurjati@gmail.com

P-ISSN: 2541-4658

E-ISSN: 2528-7427

tersebut dapat disimpulkan bahwa lahirnya tiga pilar sebagai suatu pedoman yang relevan dengan kebutuhan dan tuntutan masyarakat, yang digunakan sebagai acuan dalam mewujudkan visi, misi dan tujuan lembaga merupakan suatu terobosan yang inovatif sehingga diharapkan mampu memberikan kontribusi yang besar guna memajukan kualitas pendidikan di Indonesia.

Afkaaruna Islamic School berdiri pada tahun 2016 dengan jumlah murid sebanyak 8 anak, pada tahun 2017 bertambah menjadi 10 anak, pada tahun 2018 bertambah lagi menjadi 64 anak, terkhir dengan jumlah anak 84 di tahun 2019. Pemaparan data tersebut menunjukkan bahwa adanya peningkatan peserta didik yang signifikan tiap tahunnya. Internasional kurikulum dengan menggunakan Bahasa Inggris sebagai pengantar merupakan daya tarik bagi orang tua untuk menyekolahkan anak mereka di Afkaaruna islamic school (Sindy Saptaa. Wawancara, 16 september 2019).

Selanjutnya mengenai makna Internasional, pertama internasional adalah istilah netral yang merujuk pada hubungan timbal balik antara dua atau lebih negara. Sedangkan kurikulum Internasional mengacu pada kurikulum yang mencangkup perspektif Internasional, hubungan antar negara semakin saling berkesinambungan sehingga mendorong siswa berinteraksi dengan orang-orang dari latar belakang dan budaya yang berbeda. Sehingga mereka akan saling menghormati satu sama lain, kedua merujuk pada tiga pilar Afkaaruna yang menempatkan islam dan budaya lokal di atas pemikiran internasional, ini memiliki arti bahwa mereka berkomitmen untuk mengembangkan warisan klasik dan praktik pendidikan Islam dengan cara menyatukan keduanya (Afkaaruna Islamic School, 2019, 4.)

Afkaaruna menyebut dirinya sebagai Madrasah Internasional dimana mereka sangat memegang nilai-nilai islam dan lokal, bukan menjadi sekolah internasional yang kebaratbaratan. Sekolah yang bersandar secara mendalam pada nilai-nilai islam dan lokal yang harus disajikan kepada komunitas global. Dengan harapan pendidikan islam yang berakar di indonesia dapat berkontribusi dalam memperkaya pendidikan islam yang ada, dalam jangka panjang dan dapat menyebarkan keindahan islam (Rahmatan lili al-alamiin) kepada orang orang di seluruh dunia (Afkaaruna Islamic School, 2019, p, 4.).

Selanjutnya pembahasan mengenai beberapa penelitian mengenai kurikulum internasional yang sedang senter dibicarakan dan dikaji keberadaannya di dunia pendidikan, 
AWLADY: Jurnal Pendidikan Anak

Homepage: www.syekhnurjati.ac.id/jurnal/index.php/awlady

Email : pgrasyekhnurjati@gmail.com

P-ISSN: 2541-4658

E-ISSN: 2528-7427

apakah memberikan nilai positif atau malah merugikan. Salah satunya Penelitian yang dilakukan oleh Kritanto, Suharno, dan Gunarhadi yang berjudul "Mendorong kebijakan lokal dalam kurikulum dasar internasional bertujuan untuk mengembangkan keterampilan menyelesaikan masalah". Merupakan penelitian yang relevan dengan penelitian yang dilakukan penulis. Hasil Penelitian tersebut adalah, evaluasi pembelajaran menunjukkan peningkatan $32.2 \%$ di kelas rata-rata dan 95,24\% dari jumlah siswa memenuhi syarat standar. Mencapai hasil keuntungan dari 0,43 menunjukkan bahwa modul yang dikembangkan baik untuk diterapkan dalam kegiatan kelas. kemampuan siswa dalam menarik kesimpulan dan mengevaluasi belum mencapai hasil yang maksimal. Hasil pengamatan telah jelas mengidentifikasi perilaku siswa ketika diberikan masalah. Kegiatan diatur dalam modul, mengambil pentingnya mempromosikan kearifan lokal untuk meningkatkan kemampuan berpikir siswa, membantu siswa untuk lebih mandiri dalam mencari solusi potensial untuk memecahkan masalah (Kristanto, Suharno, dan Gunarhadi, 2019)

Ide untuk mempromosikan kearifan lokal sejalan dengan penelitian yang dilakukan oleh Ardiansyah, Suharno, dan Triyanto (2018). Yang berjudul "Pelaksanaan warisan budaya melalui pembelajaran di sekolah dasar di era disruptive studi kasus di Kota Surakarta", dilaksanakan oleh peneliti dipromosikan dalam dua bentuk utama yaitu (1) melalui program budaya warisan pembiasaan kehidupan sehari-hari dalam pembelajaran yaitu dengan menerapkan penggunaan bahasa Jawa sebagai alat komunikasi dalam pelaksanaan pembelajaran dan menyanyikan lagu-lagu daerah; dan (2) mengintegrasikan materi warisan budaya dalam mata pelajaran seperti seni meliputi tari Jawa, atau sebagai kegiatan ekstrakurikuler berupa Seni Karawitan. Bahasa dan warisan budaya Jawa menjadi fokus penelitian ini (Ardiansyah, Suharno, dan Triyanto 2018).

Penelitian dari Qomariyah dengan judul "dampak dari model pembelajaran berbasis pembelajaran untuk meningkatkan hasil pembelajaran siswa”, menyatakan bahwa pembelajaran berbasis lokal budaya yang dikembangkan dalam penelitian ini efektif untuk meningkatkan kemampuan analisis siswa. Siswa akan lebih mudah bagi mereka untuk juga memahami materi pelajaran dengan menghubungkan dengan lingkungan dan budaya yang ada di sekitar mereka. budaya lokal terintegrasi dalam pembelajaran untuk mengembangkan keterampilan analitis siswa (Qomariyah 2019). 
AWLADY: Jurnal Pendidikan Anak

Homepage: www.syekhnurjati.ac.id/jurnal/index.php/awlady

Email : pgrasyekhnurjati@gmail.com

P-ISSN: 2541-4658

E-ISSN: 2528-7427

Hal Ini berkorelasi dengan hasil penelitian yang dilakukan oleh Sasmitatias (2018). Sasmitatias menyarankan menggunakan ilmu belajar yang dirancang dengan menggunakan budaya lokal untuk mempelajari aktivitas ilmu pengetahuan. Melampirkan budaya lokal dalam belajar sejalan dengan penelitian ini untuk mempromosikan kearifan lokal dalam modul IPC. kit berbasis subjek, yaitu ilmu pengetahuan, seperti yang dipromosikan oleh Sasmitatias memiliki pendekatan yang berbeda untuk penelitian ini, sebagai penelitian ini lebih menekankan pada menciptakan modul berbasis tematik mengikuti struktur dalam Kurikulum Internasional Primer (Sasmitatias dan Kuswanto, 2018)

Beberapa hasil temuan yang relevan di atas merupakan penelitian dengan obyek lembaga pendidikan pada tingkat sekolah dasar. International Primary Curriculum dengan international Presschool curriculum keduanya memiliki kesamaan dalam tujuan pendidikan yaitu membantu anak memiliki karakter yang dengan mengintegrasikan lingkungan sekitar atau lokal budaya, sehingga anak akan tumbuh menjadi dewasa yang berkarakter kuat dengan ciri khas dirinya sendiri. salah satu ciri yang menonjol dari IPC baik untuk sekolah dasar atau usia dini adalah sama sama memberikan ruang kepada anak untuk melakukan aktivitas mengembangkan kemampuan berfikir kreatif dalam merangsang siswa untuk menganalisis masalah, memperkirakan jawaban, mencari data dan menyimpulkan jawaban terhadap masalah.

Selanjutnya pembahasan mengenai Afkaaruna Islamic School atau RA Afkaaruna sebagai salah satu lembaga yang berbasis islam dibawah naungan Kementrian Agama. dikutip dari keputusan Mentri Agama Nomor 792 Tahun 2018 tentang pedoman Implementasi Kurikulum Raudhatul Athfal BAB I yang menyatakan bahwa, Sebagai lembaga di bawah pembinaan Kementrian Agama, lembaga tersebut harus memiliki perbedaan dengan pendidikan anak usia dini secara umum. Raudlatul Athfal (RA) menitik beratkan pada aspek perkembangan, transformasi dan internalisasi nilai-nilai spiritual keislaman. Standar mutu RA terletak pada nilai-nilai keagamaan yang melekat pada seluruh komponen RA. Tidak hanya sebagai lembaga pendidikan usia dini, tetapi juga sebagai embrio pendidikan moral generasi muda dan pengenalan nilai islam sejak usia dini (Kementerian Agama, 2017)

Dalam keputusan Kementrian agama menyatakan bahwa, perlunya sebuah kurikulum RA yang menggambarkan kekhasan, keunikan dan keragaman sebagai satuan pendidikan 
AWLADY: Jurnal Pendidikan Anak

Homepage: www.syekhnurjati.ac.id/jurnal/index.php/awlady

Email : pgrasyekhnurjati@gmail.com

P-ISSN: 2541-4658

E-ISSN: 2528-7427
Vol. 6, No. 2, September 2020

agama islam yang memperjuangkan pendidikan anak bangsa. Madrasah Internasional merupakan salah satu intepretasi keunikan dan kekhasan dari Afkaaruna Islamic School. Konsep yang ditawarkan tidak hanya menonjolkan spiritual saja, internasional dan tidak meninggalkan budaya lokal adalah sebuah inovasi yang sangat luar biasa, sehingga diharapkan mampu mengembangkan potensi yang lebih baik pada anak.

Kekhasan dan keunikan tersebut dapat dilihat dari Visi Afkaaruna islamic school yaitu mempersiapkan siswa untuk menjadi al-insaanal-kamil dan warga global yang berakar secara lokal, sedangkan nilai inti sekolah islam Afkaruna telah dibangun untuk mengikuti konsep menyelaraskan tiga pilar; memiliki penekanan pada tiga pilar tersebut; memberikan stimulasi positif melalui kegiatan belajar yang kreatif dan ramah anak. Tujuan madrasa bagi siswa adalah untuk mengembangkan keingintahuan Intelektual serta pendekatan yang hidup dan inovatif untuk kehidupan. akan dikaitkan dengan nilai nilai islam ketika siswa belajar untuk menjunjung tinggi nilai nilai lokal dan internasional (Afkaaruna Islamic School, 2019, 4)

Berdasarkan beberapa hasil lapangan diatas dapat diketahui bahwa, Afkaaruna mengkolaborasi kurikulum antara Kemenag dengan Internasional kurikulum (IPC), kemudian didapatkan data melalui wawancara bahwa setelah mengkaji keduanya lahir lah kurikulum Afkaaruna sendiri yaitu "Afkaaruna Integrated Education System (AFIES)". Dalam merumuskana kurikulum yang digunakan, Afkaaruna Islamic School memiliki Direktorat Art yang didalamnya terdapat staff khusus atau kelompok kerja (POKJA) tugasnya adalah mengembangkan dan bertanggung jawab terhadap kurikulum yang diterapkan.

Dalam mengembangkan pembelajaran di Afkaaruna, framework merupakan salah satu acuan untuk mencapai visi dan memperkuat nilai nilai, kerangka berfikir yang dikolaborasikan antara kurikulum IPC dengan Kurikulum dari Kemenag (Sindy Sapta, Wawancara, 16 september 2019). 


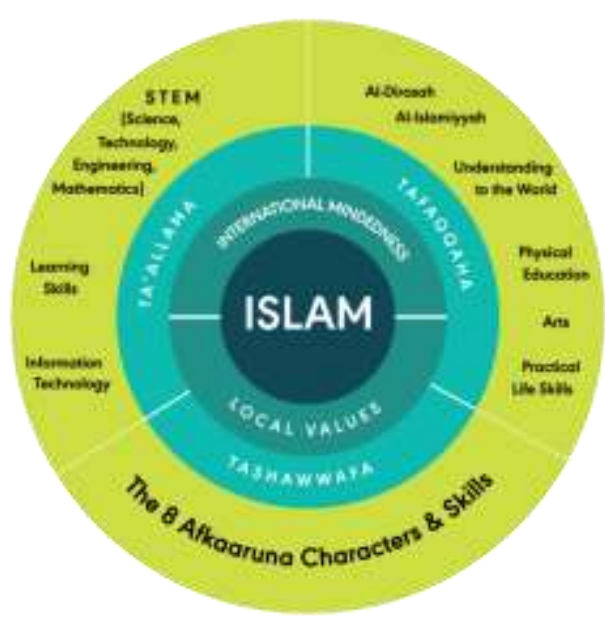

Sumber: https://www.afkaaruna.sch.id/our-learning-framework/ Gambar: Afkaaruna Islamic School's Framework

Untuk mengimplementasikan kerangka belajar yang telah dirumuskan, dimulai dengan mengidentifikasi dimensi pembelajaran menjadi tiga, yaitu; Ta'allama, Tafaqqaha, dan Tashawwafa. penjelasan dari masing masing dimensi yaitu sebagai berikut; 1. Ta'allama, Afkaaruna Islamic School bercita-cita untuk menciptakan generasi "Muhibbulilmi" (keinginan yang kuat untuk belajar). Untuk mencapai itu, mereka menentukan beberapa keterampilan belajar yang dibangun dan diperkuat pada siswa untuk. merangsang keingintahuan mereka melalui kegiatan belajar yang diselenggarakan; 2. Sekolah Islam Tafaqqaha Afkaaruna bercita-cita untuk menciptakan generasi tafaqquh fial-diin (terampil dan menjunjung tinggi pemikiran Islam) Ahlussunnah Wal Jama 'ah yang siap menjadi warga global dengan kesadaran lokal yang kuat;3. Tashawwafa Afkaaruna Islamic School bercita-cita untuk menciptakan generasi yang baik hati yang memiliki 8 keterampilan utama dan kompetensi karakter termasuk kemandirian( keterampilan belajar mandiri), komunikasi, pemikiran kritis, kreativitas, kolaborasi sebagai syarat untuk mengembangkan pembelajar seumur hidup. Untuk mencapai keterampilan hidup, yaitu dengan cara melatih siswa dalam keterampilan membaca, keterampilan berhitung, keterampilan keuangan, dan kesadaran sosial (Afkaaruna Islamic School, 2019, 9).

Jika ditinjau dari segi model pembelajaran, beberapa aspek di dalam International Mindednes terdapat kemiripan dengan model pembelajaran STEAM (Science, Technology, Engineering, Art, and Mathematics). Sama sama fokus pada pemahaman integrasi disiplin 
AWLADY: Jurnal Pendidikan Anak

Homepage: www.syekhnurjati.ac.id/jurnal/index.php/awlady

Email : pgrasyekhnurjati@gmail.com

P-ISSN: 2541-4658

E-ISSN: 2528-7427

sains, teknologi, teknik, seni dan matematik. Pembahasan mengenai STEAM dapat dilihat melalui hasil penelitian oleh Wahyuningsih dkk. Yang menyatakan bahwa dengan model pembelajaran STEAM, dapat meningkatkan kreativitas dalam berpikir anak usia 5-6 tahun serta Mampu memecahkan masalah dalam kehidupan nyata (Siti Wahyuningsih dkk. 2019).

Hal tersebut sesuai dengan data hasil wawancara dengan kepala sekolah yang menyatakan bahwa, upaya guna menggali pemikiran kreatif dan sikap keingintahuan selalu dilakukan setiap pembelajaran di Kindy Afkaaruna melalui kegiatan yang bervariasi dikemas dengan hal hal yang menyenangkan sehingga menstimulus anak agar mampu menyelesaikan masalah nya di dunia nyata (Sindy Sapta, 26 Desember 2020). Hanya saja konsep dan pengaplikasian kegiatan sedikit berbeda.

Selanjutnya, pembahasan mengenai Local Value yang dikembangkan melalui delapan keterampilan Tashawaffa dikemas dalam satu konsep yang disebut Afkaaruna Values \& Character Education (AVCE). Sebagai jantung sistem pendidikan AFIES yang telah dibangun untuk mengikuti konsep menyelaraskan 3 pilar Afkaaruna. 8 AVCE dikembangkan secara unik untuk mencapai tujuan akademik sekolah. Diambil dari prinsip prinsip tashawwafi yang disinkronkan dengan karakter abad ke-21 dan, akhirnya dibagi menjadi tiga bidang yaitu keterampilan manajemen al-Qalb, keterampilan pribadi dan kesadaran sosial, dan keterampilan (Afkaaruna Islamic School, 2019, p, 22)

Manajemen Al-Qalb (Hati) adalah nilai inti yang mendasar bagi orang baik yang berasal dari nilai nilai Islam. Keterampilan ini dianggap sebagai dasar karakter yang memberikan kompas untuk berperilaku. Al-Qalb dapat membimbing siswa secara efektif mengelola hati mereka dan membantu mereka untuk membuat pilihan yang bertanggung jawab.Nilai yang meliputi manajemen Al-Qalb adalah Shiddiq, Ikhlas, dan Tahammul. Nilai keterampilan pribadi meliputi disiplin dan kemandirian. Dan nilai keterampilan kesadaran sosial terdiri dari keterampilan, pengetahuan, mengelola hubungan secara efektif, menyelesaikan konflik serta dapat mengambil keputusan yang bertanggung jawab termasuk dalam komunikasi dan adaptasi serta kepemimpinan (Afkaaruna Islamic School, 2019, p, 23)

Tujuan dari AVCE adalah untuk menanamkan karakter dan membangun kompetensi pada siswa untuk menjadi individu muslim yang baik yang menghormati nilai nilai lokal, bangga dengan negara asalnya dan siap berkontribusi untuk visi global. Yang sejalan dengan 
AWLADY: Jurnal Pendidikan Anak

Homepage: www.syekhnurjati.ac.id/jurnal/index.php/awlady

Email : pgrasyekhnurjati@gmail.com

P-ISSN: 2541-4658

E-ISSN: 2528-7427
Vol. 6, No. 2, September 2020

visi dari Afkaaruna Islamic School. Pengembangan karakter dapat dilakukan melalui role model, strategi pembiasaan, Quotes Wise (kata mutiara) atau mahfudhot, penghargaan dan hukuman,kebiasaan baik seperti yang disebutkan dan ditampilkan dalam setiap aturan di kelas, atau ketika circletime, atau ketika evaluasi setelah pembelajaran. Orang tua juga diminta memberikan evaluasi tentang kebiasaan anak dirumah. Jadi, AVCE dirancang khusus untuk menumbuhkan karakter diri dalam ranah Tashawwafa (Afkaaruna Islamic School, 24)

Strategi yang digunakan dalam penerapan AVCE, yaitu dengan;1. kegiatan kokurikuler meliputi proyek seni (kerajinan, lukisan, menggambar dan kaligrafi), seni dan budaya Islam (hadrah dan shalawat), olahraga (pencak silat seni bela diri), pramuka, dan proyek penelitian. 2. Program pengembangan karakter terstruktur guna mempersiapkan karakter yang kuat bagi peserta didik dalam dunia globalisasi, beberapa program seperti; newsday (seminggu sekali) anak diminta membawa barang dari rumah untuk di presentasikan di kelas; Saving Day (setiap minggu dan kamis) siswa membawa uang dan menyimpan di koprasi "Afkaa Sejahtera Bersama" yang akan diambil pada akhir tahun pembelajaran; infaq day (seminggu sekali, pada hari jum'at) siswa membawa uang untuk infaq dan amal; Ten Minutes For Environment (setiap hari) siswa terlibat dalam kegiatan yang berfokus pada lingkungan yang meningkatkan kesadaran, memahami dan menghormati kelestarian lingkungan alam; Crafterpreneur Day \& Market Day, siswa sekolah dasar diminta untuk mempromosikan produk berdasarkan tema atau subjek yang dijalankan selama semester dibantu oleh pendidik para siswa kemudian menjualnya di Market Day (Afkaaruna Islamic School, t.t., 25)

Berdasarkan pemaparan data di atas dapat diambil kesimpulan bahwa, Local Value yang dimaksud dalam tiga Pilar Afkaaruna Islamic School adalah memiliki karakter diri, memahami norma dan aturan yang berlaku di masyarakat sekitar. Local value dan kearifan lokal adalah dua istilah yang memiliki persamaan makna, dimana keduanya sama sama menerapkan nilai dan norma yang berlaku di masyarakat. Salah satu ruang lingkup budaya kearifan lokal adalah permainan. Hasil penelitian oleh Suyadi menyatakan bahwa, permainan menyusun balok seimbang becak dan mainan susun balok andong, seimbang dengan kearifan lokal budaya Yogyakarta (Suyadi dan Issaura Dwi Selvi, 2019). 
AWLADY: Jurnal Pendidikan Anak

Homepage: www.syekhnurjati.ac.id/jurnal/index.php/awlady

Email : pgrasyekhnurjati@gmail.com

P-ISSN: 2541-4658

E-ISSN: 2528-7427
Vol. 6, No. 2, September 2020

Secara umum tiga unit sekolah islam Afkaaruna yang meliputi Afkaaruna Preschool, Afkaaruna Kindy, dan Primary Afkaaruna didasarkan pada kerangka yang sama. Yang membedakan ketiga unit ini adalah kedalaman dan luasnya Framework sehingga implementasi, target, pembelajaran, metode dan pengukuran juga berbeda (Sindy. Saptaa. Wawancara, 16 september 2019).

Afkaaruna Kindy menggunakan Kurikulum Utama Internasional (IPC) yang disinkronkan dengan Paket Belajar Afkaaruna (ALP) yang mencakup bahasa Inggris, alDirasah al-Islamiyyah, dan nilai-nilai lokal. Literasi disampaikan dalam dua bahasa; Bahasa Indonesia dan Bahasa Inggris. Belajar membaca secara sistematis diberikan kepada siswa Kindy B dengan metode Phonic dan pengantar surat disampaikan melalui kartu flash (Sindy. Sapta. Komunikasi Pribadi). Lulusan Afkaaruna yang Baik diharapkan untuk tumbuh sesuai dengan usia mereka dan siap untuk mengambil bagian dalam pendidikan dasar lebih lanjut. Selain itu, mereka juga diharapkan memiliki keterampilan dasar yang baik dalam membaca Qur 'an (Afkaaruna Islamic School, 11). Berikut Framework dari kindy Afkaaruna Islamic School:

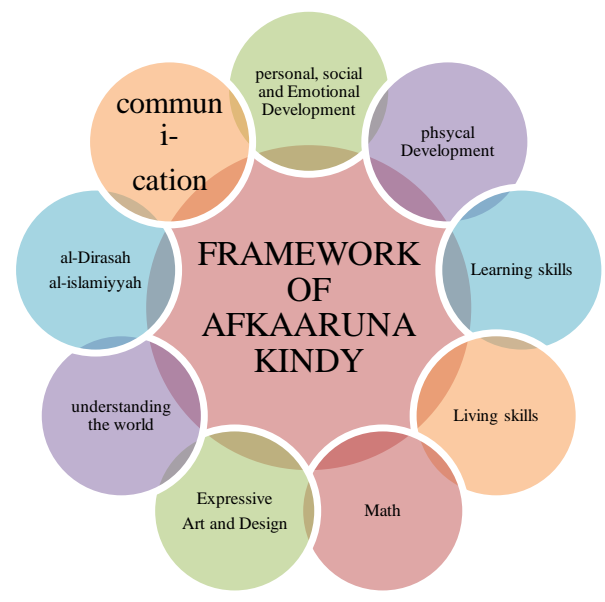

Gambar: Framework Pembelajaran Kindy B Afkaaruna islamic School

Berdasarkan framework di atas, dapat diketahui bahwa dalam menerapkan pembelajaran kindy Afkaaruna mengacu pada 9 aspek yaitu Living Skills, Learning Skills, Physical Development, Personal, Social and Emotional Development, Communication, Dirassah Al Islamiyah, Understanding the World, Expressive Art and Design serta Math. Beberapa aspek tersebut merupakan gabungan dari Framework IPC dan Kemenag yang 
AWLADY: Jurnal Pendidikan Anak

Homepage: www.syekhnurjati.ac.id/jurnal/index.php/awlady

Email : pgrasyekhnurjati@gmail.com

P-ISSN: 2541-4658

E-ISSN: 2528-7427

kemudian dikolaborasi menjadi satu kesatuan dalam kurikulum AFIES. yang membedakan kurikulum keduanya yaitu pada Kompetensi inti dan Kompetensi Dasar, dalam IPC mereka menyebutnya Learning strands. Secara garis besar keduanya memiliki persamaan, hanya kuantitas jumlah kompetensi IPC lebih banyak dan bervariasi daripada Kompetensi yang dimiliki Kemenag. Pada kurikulum Kemenag, standar tingkat pencapaian perkembangan anak ada 6 (agama dan moral, kognitif, seni, motorik, bahasa dan sosem), (Sindy Saptaa. Wawancara, 16 september 2019).

Learning skills dan living skills adalah dua aspek yang menjadi ciri khas dari kurikulum IPC. Learning skills meliputi loka karya mini, program kebiasaan membaca dan proyek pembelajaran terstruktur. Desain tersebut akan meningkatkan kapasitas siswa untuk menjadi siswa yang mandiri, memiliki karakter pribadi, dan menumbuhkan motivasi belajar. Keterampilan ini dikembangkan melalui proyek sains dan penelitian serta melalui kurikulum tersembunyi di semua mata pelajaran sebagai bagian dari upaya memicu kemampuan siswa melalui pertanyaan menggunakan $5 \mathrm{~W}+1 \mathrm{H}$. Pada saat yang sama, pembelajaran kontekstual juga digunakan dalam setiap kegiatanpembelajaran. Dengan serangkaian kegiatan tersebut diharapkan siswa akan memiliki kemampuan untuk belajar secara mandiri dan memiliki kreativitas yang baik. memiliki keterampilan belajar yang baik memungkinkan siswa untuk dapat merencanakan, mengatur, melaporkan, mengevaluasi masalah dan mampu menyelesaikannya. Keahlian belajar ini dapat merangsang kreativitas. Berbeda dengan pemikiran kritis, kreativitas dapat diperoleh jika kita dapat menghasilkan ide, kreativitas dapat dibangun di dalam lingkungan yang kondusif sehingga memungkinkan siswa untuk berfikir berbeda dalam meningkatkan pertanyaan dam memiliki proyek independen. Afkaaruna juga merangsang kolaborasi antara keduanya, dengan kolaborasi melalui pembelajaran kelompok sebaya, dapat ditanamkan karakter Afkaaruna seperti komunikasi dan adaptasi (Afkaaruna Islamic School, 2019, p, 26)

Living Skills adalah bagian penting dari kurikulum untuk semua siswa di Afkaaruna. Perencanaan kurikulum yang cermat di seluruh madrasah memberi kesempatan pada siswa untuk mengalami dan belajar mempersiapkan diri dalam kehidupan nyata, seperti menyebrang jalan, merencanakan makanan mereka sendiri atau berbelanja. Selain itu, living skills juga dirancang untuk mengembangkan karakter termasuk manajemen diri. Keahlian Numerik 
AWLADY: Jurnal Pendidikan Anak

Homepage: www.syekhnurjati.ac.id/jurnal/index.php/awlady

Email : pgrasyekhnurjati@gmail.com

P-ISSN: 2541-4658

E-ISSN: 2528-7427

dikembangkan melalui matematika terapan. Kesadaran sosial dan kewarganegaraan dibangun melalui pramuka, studi sosial, dan proyek sosial. Keterampilan digital dikembangkan melalui ilmu komputer (Afkaaruna Islamic School, 2019, p, 26).

Hasil wawancara diketahui bahwa, dengan banyaknya kompetensi yang diterapkan di Afkaaruna. Pembelajaran di dalamnya akan lebih banyak dan bervariasi (Sindy Sapta, Wawancara, 16 september 2019) Berikut IPC learning strands dalam satu hari. Data di ambil dari Rancangan Program Pembelajaran Harian (RPPH) kindy B.Semester 1 pada Senin, 2 september 2019 dengan tema besar How Are You, sub tema Eating the right foods.

Tabel. Rancangan Program Pembelajaran Harian (RPPH) Kindy B.

\begin{tabular}{|c|c|}
\hline $\begin{array}{l}\text { IPC Learning } \\
\text { Strands }\end{array}$ & Indicators \\
\hline Life skill & $\begin{array}{l}\text { 1.1.2. Managing Personal belonging } \\
\text { 1.2.2. Be able to hand leequipment and tools effectively including }\end{array}$ \\
\hline Learning skill & $\begin{array}{l}\text { 2.1.2. Interested to open or read a book. } \\
\text { 2.2.1. Be able to read simple and familiar words (English and bahasa) }\end{array}$ \\
\hline $\begin{array}{l}\text { Communication \& } \\
\text { Language }\end{array}$ & $\begin{array}{l}\text { 3.1.1. Listening attentively and responding appropriately to others. } \\
\text { 3.2.2. Understanding non-verbal messeges } \\
\text { 3.3.2 Explanning, listening to others, taking part in reflective disscussion, planning } \\
\text { and observing. }\end{array}$ \\
\hline Physical Education & $\begin{array}{l}\text { 4.1.2 Actively exploring playground } \\
\text { 4.2.2 Self help and self care }\end{array}$ \\
\hline Dirasah islamiyah & $\begin{array}{l}\text { 5.1 Be able to read yanbu'a } \\
5.2 \text { Be able to write Hijaiyyahl etter } \\
5.3 \text { Be able to memorize surah } \\
5.4 \text { Be able to memorize daily du'a } \\
5.5 \text { Be able to follow how to perform wudhu and sholat, including what words to } \\
\text { say and the correct movements. } \\
\text { 5.6 Be able to memorize Mahfudhot (8 mahfudhot) }\end{array}$ \\
\hline Math & 6.1.3 Enjoying and using number (upto 30) \\
\hline $\begin{array}{l}\text { Understanding the } \\
\text { world }\end{array}$ & $\begin{array}{l}\text { 7.2.2 Understandingt hat events and people's actions have causes and effects } \\
\text { 7.3.1 Know about the basic conditions needed for living things to survive }\end{array}$ \\
\hline $\begin{array}{l}\text { Creative Art \& } \\
\text { Design }\end{array}$ & 8.1.3 Enjoying and using music, art, drama and dance. \\
\hline $\begin{array}{l}\text { Personal sosial } \\
\text { emotional } \\
\text { development }\end{array}$ & $\begin{array}{l}\text { 9.1.2 Their ability to acquire new interest sands kills } \\
\text { 9.1.3 Enjoying and using music, art, drama, and dance } \\
\text { 9.2.2 Their relationship with others } \\
\text { 9.2.3 Using different media to express a mood or feelin or for representing } \\
\text { information } \\
\text { 9.3.2 Helping others } \\
\text { 9.3.4 Empathizing with others }\end{array}$ \\
\hline
\end{tabular}

Berdasarkan gambar diatas dapat diketahui bahwa dalam satu kompetensi dasar terdapat beberapa indikator yang harus dicapai anak dalam satu hari. Kegiatan yang bervariasi 
AWLADY: Jurnal Pendidikan Anak

Vol. 6, No. 2, September 2020

Homepage: www.syekhnurjati.ac.id/jurnal/index.php/awlady

Email : pgrasyekhnuriati@gmail.com

P-ISSN: 2541-4658

E-ISSN: 2528-7427

guna membantu tercapainya indikator tersebut dapat diketahui melalui Weekly Plan atau Rancangan Program Pembelajaran Mingguan (RPPM) di bawah ini.

Tabel. Rancangan Program Pembelajaran Mingguan Kindy Afkaaruna.

\begin{tabular}{|c|c|c|}
\hline MONDAY & TUESDAY & WEDNESDAY \\
\hline $\begin{array}{l}\text { Circletime } \\
\text { - Opening } \\
\text { - Weather, day, and date } \\
\text { - Assalamualaikum song } \\
\text { - Reading book } \\
\text { - News day }\end{array}$ & $\begin{array}{l}\text { Circletime } \\
\text { - Opening } \\
\text { - Weather, day, and date } \\
\text { - Break w and } 2 \\
\text { - Reading book } \\
\text { - News day }\end{array}$ & $\begin{array}{l}\text { Circletime } \\
\text { - Opening } \\
\text { - Weather, day and date } \\
\text { - Afkaaruna song } \\
\text { - Readingbook } \\
\text { - News day }\end{array}$ \\
\hline Flag ceremony & Wudhu \& sholat dhuha & Wudhu \& sholat dhuha \\
\hline $\begin{array}{l}\text { Reasearch and recording } \\
\text { activity Simulation to teach } \\
\text { hand washing and tooth } \\
\text { brushing }\end{array}$ & $\begin{array}{l}\text { Reaserch and recording } \\
\text { Activity } \\
\text { Walk around and find kinds } \\
\text { of foods (rice, fruit, milk, } \\
\text { egg, and vegetables) }\end{array}$ & $\begin{array}{l}\text { Performing Art } \\
\text { Bring their own music instrument by } \\
\text { making from sealed plastic cup with } \\
\text { beans inside and play it together }\end{array}$ \\
\hline $\begin{array}{l}\text { IPC } \\
* \text { EntryPoint* } \\
\text { (dance, yoga, etc and } \\
\text { watching video: how germget } \\
\text { inside the body) }\end{array}$ & $\begin{array}{l}\text { IPC } \\
\text { Learn about balance diet }\end{array}$ & $\begin{array}{l}\text { IPC } \\
\text { Learn about healty and unhelaty food. }\end{array}$ \\
\hline $\begin{array}{l}\text { Mathematics } \\
\qquad \quad \text { Addition 1-10 } \\
\text { Work sheet about addition 1- } \\
10\end{array}$ & 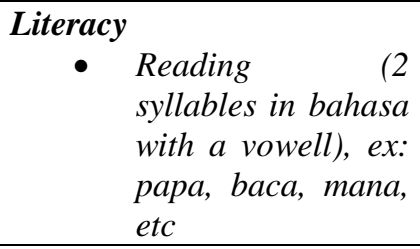 & $\begin{array}{l}\text { Mathematics } \\
\qquad \quad \text { Addition 1-10 } \\
\text { Work sheet about addition 1-10 }\end{array}$ \\
\hline
\end{tabular}

Surah:

Mahfudhot :

Du'a :

Song:

Book: Generosity

\begin{tabular}{|c|c|}
\hline TUESDAY & FRIDAY \\
\hline $\begin{array}{l}\text { Circletime } \\
\text { - } \quad \text { Opening } \\
\text { - Weather, day, anddate } \\
\text { - Sing "we are happy family" song } \\
\text { - Reading book } \\
\text { - News day }\end{array}$ & $\begin{array}{l}\text { Circletime } \\
\text { - Opening } \\
\text { - Weather, dayanddate } \\
\text { - Sing "how are you?" song } \\
\text { - Reading "book Vi "tues Moral Excellent Generosity", } \\
\text { - News Day }\end{array}$ \\
\hline Wudhu\&sholatdhuha & Physical education/exercise \\
\hline $\begin{array}{l}\text { Reaserch and recording Activity } \\
\text { Walk around madrasa and find helaty } \\
\text { foods. }\end{array}$ & $\begin{array}{l}\text { Dolanan Anak } \\
\text { Nekeran }\end{array}$ \\
\hline $\begin{array}{l}\text { IPC } \\
\text { Asking student about their dietary and } \\
\text { arrange their own menu breakfast and } \\
\text { lunch }\end{array}$ & $\begin{array}{l}\text { IPC } \\
\text { Review the lesson for this week }\end{array}$ \\
\hline $\begin{array}{l}\text { Literacy } \\
\text { - Reading (2 syllables in bahasa with }\end{array}$ & $\begin{array}{l}\text { Enviroment Day } \\
\text { - } \quad \text { Cleaning and tidying food waste }\end{array}$ \\
\hline
\end{tabular}




\begin{tabular}{l|ll}
\hline \multicolumn{1}{c}{ a vowel), ex: papa, baca, mama, dll } & $\bullet \quad \begin{array}{l}\text { Watering plants } \\
\text { Caring for plants }\end{array}$ \\
\hline OTHER & \\
Rules: & \\
Say permission before go to toilet & \\
\hline
\end{tabular}

Berdasarkan tabel kegiatan pembelajaran di atas, dapat diambil kesimpulan bahwa, dalam satu hari terdapat empat kegiatan utama yang sudah disusun berdasarkan program pembelajaran yang ditawarkan di Kindy Afkaaruna. Kegiatan Pertama, Circle time yang berisi pembukaan; bercakap cakap tentang cuaca, nama hari dan tanggal; ice breaking berupa nyanyian yang bervariasi setiap harinya; membaca buku, yaitu guru membacakan buku yang berbeda setiap harinya, disesuaikan dengan tema atau goals yang ingin dicapai pada hari tersebut; dan News day, dengan tujuan mengembangkan sikap percaya diri anak untuk mendemonstrasikan suatu benda di depan teman temannya, point pertama ini mengacu pada pengembangan personal, sosial emosional dan komunikasi. Kegiatan kedua, adalah pengembangan aspek keislaman dengan pembiasaan sholat dhuha bersama, membaca iqro, hafalan surah, hadis dan mahfudhot yang mengacu pada al-dirassahal-islamiyah, selanjutnya, upacara bendera setiap hari senin;

Kegiatan ketiga, pengenalan angka, huruf atau aksara yang dilakukan secara bergantian setiap hari nya, point ini mengacu pada framewok "Math". Environment day pada hari Jum'at, anak anak ditanamkan cinta lingkungan dan kebersihan adalah sebagian dari iman. Kegiatan Kempat, adalah program kegiatan dilaksanakan setiap hari dengan sub kegiatan yang berbeda beda seperti Program Research and Recording Activity meliputi Mini Project yang dilakukan setiap hari senin, Outdoor Investigation yang dilakukan setiap hari selasa dan kamis, Performing Art, pengenalan seni seperti musik, teater, rebana, melukis, dan lainnya yang dilakukan setiap hari Rabu. Dolanan anak dikenalkan tarian, permainan, pakaian, makanan dan nyanyian tradisional dan IPC review yang dilakukan setiap hari jum'at;

Hasil wawancara dengan kepala sekolah yang menyatakan bahwa, dalam menyusun perencanaan baik harian, mingguan, semester atau tahunan, dilakukan bersama dengan guru, kepala sekolah dan seluruh POKJA direktorat Art. Pada akhir tahun pembelajaran seluruh perencanaan tersebut disusun secara sistematis. Beberapa kendala yang telah dipaparkan oleh narasumber bahwa mereka membutuhkan waktu yang cukup lama, dikarenakan mereka harus menyusun seluruh perencanaan hingga RPPH, yang seharusnya dikerjaka satu hari sebelum 
AWLADY: Jurnal Pendidikan Anak

Homepage: www.syekhnurjati.ac.id/jurnal/index.php/awlady

Email : pgrasyekhnurjati@gmail.com

P-ISSN: 2541-4658

E-ISSN: 2528-7427

Pembelajaran dimulai dan RPPM yang seharusnya dikerjakan setiap akhir pekan. Kendala selanjutnya yaitu mereka harus menerjemahkan seluruh dokumen menggunakan bahasa inggris yang juga memerlukan banyak waktu (Sindy Saptaa. Wawancara, 16 september 2019).

Narasumber menambahkan, dalam pelaksanakan perencanaan pembelajaran tersebut, mereka mendapatkan pelatihan dan pembinaan dari kurikulum IPC yang diselenggarakan oleh pihak lisensi. Pembinaan dari cara mengajar, mengimplementasikan kurikulum IPC, hingga bagaimana cara membangun sebuah lembaga pendidikan berbasis IPC. Selain itu, mereka juga mendapatkan suatu buku pedoman dalam bentuk hard file dan soft file (Sindy Saptaa. Wawancara, 16 september 2019).

Pembinaan yang diselenggarakan oleh pihak lisensi sangat membantu lembaga sekolah dalam mengembangkan sistem manajemen kurikulum mereka. Kurikulum IPC yang dikembangkan oleh Afkaaruna Islamic School melahirkan suatu ide atau gagasan baru yang berbeda dari sebelumnya. Sehingga menjadi daya tarik tersendiri bagi lembaga sekolah yang mampu menumbuhkan kepercayaan orang tua untuk menyekolahkan anak mereka di Afkaaruna Islamic School.

\section{SIMPULAN}

Berdasarkan temuan dan hasil pembahasan penelitian " pengembangan kurikulum Integratif Islam, local value, International mindedness di Kindy Afkaaruna Islamic School", menyimpulkan bahwa dalam pengembangan tiga aspek kurikulum tersebut, mengacu pada kurikulum IPC yang dikolaborasikan dengan kurikulum kemenag, disinkronkan dengan paket belajar Afkaaruna Learning Pack (ALP) mencakup bahasa inggris, al-Dirassah al-Islamiyah dan nilai lokal. Penerapan pembelajaran di Kindy Afkaaruna mengacu pada Framework yang meliputi; living skills, learning skills, physical development, personal, social and emotional development, communication, al-dirassah al-islamiyah, understanding the world, expressive Art and design serta Math. Program unggulan yang ditawarkan meliputi Mini Project, Outdoor Investigation, Performing Art, Enviromentda, Dolanan Anak, News Day, pengenalan mahfudhot dan iqro dengan metode Ummi'. Kegiatan IPC yang di dalamnya mengacu learning skill dan living skill dengan menyesuaikan tema hari tersebut.

Kurikulum Integratif Islam dikembangkan melalui indikator kurikulum 13 dari Kemenag yang mengacu pada 6 aspek perkembangan anak. Beberapa indikator yang diadopsi 
adalah berkaitan dengan aspek agama. Nilai Lokal dikembangkan melalui beberapa program pembelajaran seperti Dolanan Anak, Enviroment Day, Saving Day, Market Day. Serta kegiatan insindental perayaan hari besar di Indonesia seperti, Hari Kartini, Hari Pahlawan, Sumpah Pemuda, Kemerdekaan Indonesia dll. Dengan tujuan memperkenalkan nilai budaya lokal di Indonesia. Selanjutnya Pengembangan karakter melalui role model menggunakan strategi pembiasaan, Quotes Wise (kata mutiara), kebiasaan baik yang disebutkan dan ditampilkan dalam setiap aturan di kelas atau ketika Circle Time, atau ketika evaluasi pembelajaran. International Mindedness dikembangkan melalui kegiatan IPC time yang dilakukan setiap hari mengikuti tema yang sedang dibahas. Kegiatan ini mengacu pada Kurikulum IPC dan dijadikan sebagai kegiatan inti dalam proses pembelajaran.

\section{DAFTAR PUSTAKA}

Afkaaruna Islamic School. 2019. "Afkaaruna Kindy - Afkaaruna Islamic School." 10 November 2019. https://www.afkaaruna.sch.id/afkaaruna-kindy/.

- t.t. Parent Information Booklet. Yogyakarta: Afkaaruna Islamic Booklet.

Ardiansyah, Roy, Suharno, dan Triyanto. 2018. "Inheritance National Culture Through Learning in Elementary School at Disruptive Era: Case Study in Surakarta Indonesia." International Journal of Educational Research Review 3 (4): 48-53.

Biro Humas Data dan Informasi Kementerian Agama. t.t. "Website Kementerian Agama RI." Diakses 10 November 2019. https://kemenag.go.id/.

Dinn Wahyudin. 2014. Manajemen Kurikulum. Bandung: PT Remaja Rosdakarya.

International Preschool Curriculum. t.t. "For Schools." International Preschool Curriculum.

Diakses 10 November 2019. http://internationalpreschoolcurriculum.com.sg/forschools.html.

Irjus Indrawan. 2012. Pengantar Manajemen Sarana Prasarana Sekolah. Yogyakarta: CV Budi Utama.

Kristanto, Agus, Suharno, dan Gunarhadi. 2019. "Promoting Local Wisdom in International

Primary Curriculum Aims to Develop Learners' Problem Solving Skills." International Journal of Educational Research Review 4 (3): 439-47.

Nasbi, Ibrahim. 2017. "MANAJEMEN KURIKULUM: Sebuah Kajian Teoritis.” Idaarah: Jurnal Manajemen Pendidikan 1 (2). https://doi.org/10.24252/idaarah.v1i2.4274.

Oemar Hamalik. 2009. Kurikulum dan Pembelejaran. Jakarta: Bumi Aksara.

Qomariyah, Siti Nurul. 2019. "Effect of Problem Based Learning Learning Model to Improve Student Learning Outcomes." International Journal of Educational Research Review 4 (2): 217-22.

Rusman. 2009. Manajemen Kurikulum. Jakarta: PT Raja Grafindo Persada.

Sasmitatias, Frastika, dan Heru Kuswanto. 2018. "The Development of Science Learning Device Based on Serukam Local Culture To Improve Students' Analytical Skill.” International Journal of Educational Research Review 3 (3): 59-68. https://doi.org/10.24331/ijere.441348. 
Siti Wahyuningsih, Adriani Rahma Pudyaningtyas, Ruli Hafidah, Muhammad Munif Syamsuddin, Upik Elok Endang Rasmani, dan Novita Eka Nurjanah. 2019. "Efek Metode STEAM pada Kreatifitas Anak Usia 5-6 Tahun." Jurnal Obsesi : Jurnal Pendidikan Anak Usia Dini Vol 4 (1 (2020)): 305-11. https://doi.org/10.31004/obsesi.v4i1.305.

Spring, J. 2009. Globalization of Education: An Introduction. New York: Taylor and Francis. Suyadi, dan Issaura Dwi Selvi. 2019. "Implementasi Mainan Susun Balok Seimbang Berbasis Kearifan Lokal Yogyakarta untuk Anak Usia Dini." Jurnal Obsesi: Jurnal Pendidikan Anak Usia Dini $4 \quad$ (1 (2020)): 385-94. https://doi.org/10.31004/obsesi.v4i1.345.

the IPC family of schools. t.t. "International Preschool Curriculum - IPC International Preschools." Diakses 10 November 2019. https://www.ipc.education/curriculum.

Wina Sanjaya. 2008. Kurikulum dan Pembelajaran. Cetakan ke 1. Jakarta: Kencana. 